\title{
Evaluation of Anti- Ulcer Activity of Tripotassium Dicitro Bismuthate (TDB) in Mice
}

\author{
Ghada A. Taqa \\ Department of Dental Basic Sciences \\ College of Dentistry \\ Mosul University
}

(Received 15 / 7 / 2009 ; Accepted 2/ 11 / 2009)

\begin{abstract}
Bismuth compounds have been used in medicine for more than 200 years to treat gastrointestinal tract disorders . Therefore, the present study was designed to investigate the gastroprotective effects of Tripotassium Dicitro Bismuthate (TDB) against HCl- ethanol induced ulcer in mice. The drug was administered to mice at 50 and $100 \mathrm{mg} \backslash \mathrm{kg}$ doses orally before one hour of receiving $0.2 \mathrm{ml}$ of $\mathrm{HCl}$ - ethanol mixture to induce gastric ulcer. Sucralfate $(100 \mathrm{mg} / \mathrm{kg}$, orally )was used as standard drug . The severity of gastromucosal damage induced by $\mathrm{HCl}$-ethanol was analyzed in term of ulcer index value. Pretreatment with TDB (50, $100 \mathrm{mg} / \mathrm{kg}$ ) produced a significant decrease in ulcer index value and increased protection against gastric ulcer when compared to saline treated group. Sucralfate (100 mg/kg, orally) also produced a significant decrease in ulcer index when compared with the saline treated group. There was no significant difference between TDB and Sucralfate in degree of protection against ulcer. Thus it was concluded that TDB has antiulcer activity in mice.
\end{abstract}

Keywords: anti-ulcer , gastroprotective, tripotassium dicitro bismuthate ,TDB , Ulcer .

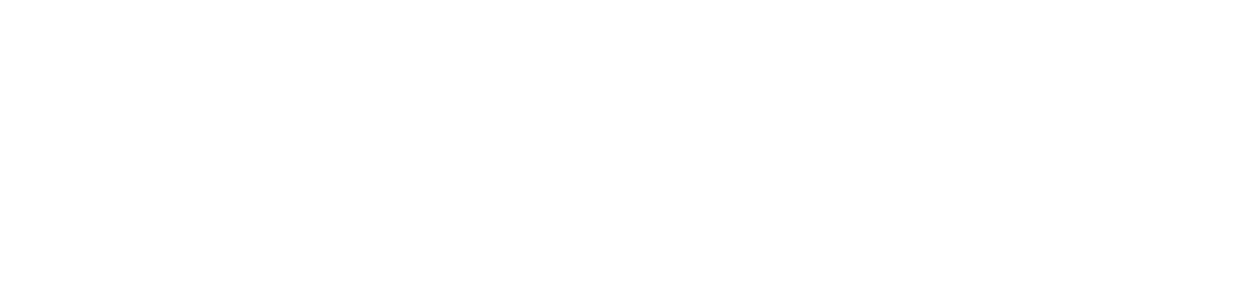

تستخم مركبلت البزموث منذ زمن بعيد في علاج اضطرابلت الجهاز الهضمي ' لذا مَ في هذه الدرلسة قيم

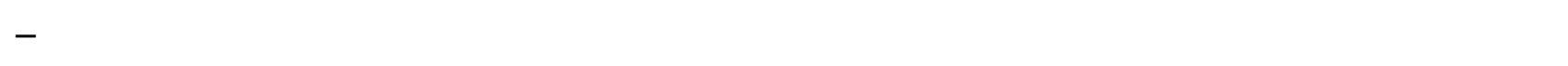

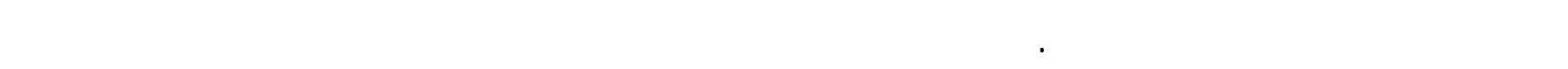

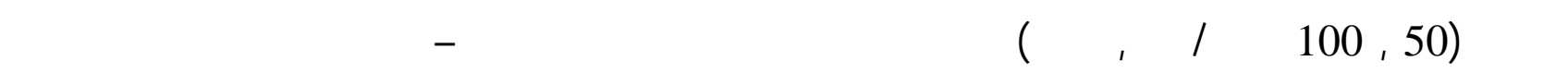

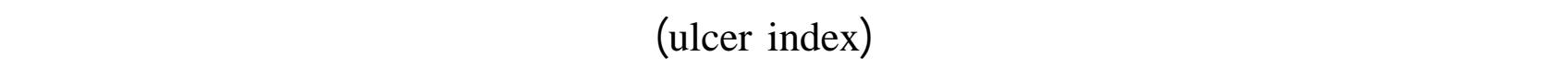
الملح الفسيولوجي . كما وأدى إعلاء دواء ل إل Sucralfate بجرعة (100 ملغم / كغم, بالفم ) في المجموعة المعلملة بمزيج الايثانول - حلمض الهايدروكلوريد إلى إحداث النخفاضا معنويا في منب القرئ القرحة مقارينة

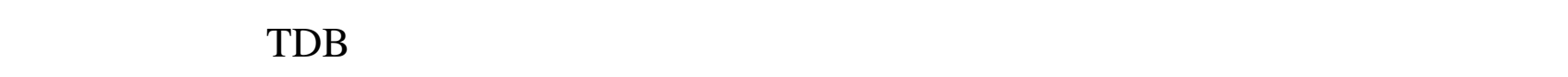


صندأ. Sucralfate ضد القرحة المحثة بمزيج الايثانول - حلمض الهايدروكلوريد لذا فمن الممكن لستخدلمه للوقاية من الإصابة جقرحة المعدة . 